\title{
Effect and mechanism of microRNA-10b on proliferation and invasion of esophageal cancer cells
}

\author{
YI LIU $^{1}$, ADILI SALAI ${ }^{2}$, DAN HE$^{2}$, SHENGLI GAO $^{2}$ and WEI ZENG ${ }^{3}$ \\ ${ }^{1}$ Department of Cardiothoracic Surgery, Shenzhen University General Hospital, Shenzhen, Guangdong 518055; \\ ${ }^{2}$ Department of Thoracic Surgery, Affiliated Tumor Hospital, Xinjiang Medical University, Urumqi, Xinjiang 830011; \\ ${ }^{3}$ Department of Hematology and Oncology, Shenzhen University General Hospital, Shenzhen, Guangdong 518055, P.R. China
}

Received August 24, 2018; Accepted June 13, 2019

DOI: $10.3892 /$ etm.2019.7940

\begin{abstract}
MicroRNA (miR)-10b is highly expressed in esophageal cancer tissues and is associated with poor prognosis of esophageal cancer. However, the role and mechanism of miR-10b in esophageal cancer cells remains unclear, therefore, the present study aimed to investigate this. Esophageal cancer cells, TE-1 and EC9706, were transfected with miR-10b mimic, miR-10b inhibitor or incubated with transforming growth factor- $\beta$ (TGF- $\beta$ ). MTT and EdU assays were used to detect cell proliferation. Flow cytometry was used to determine cell cycle analysis and apoptosis. Cell migration and invasion were also analyzed. Western blot analysis was used to detect protein levels and reverse transcription-quantitative PCR was used to analyze miR-10b expression. The present results demonstrated that, compared with the control group, miR-10b significantly promoted TE-1 and EC9706 cell proliferation. Compared with miR-10b inhibitor group and control group, miR-10b mimic promoted esophageal cancer cell cycle progression, inhibited apoptosis of esophageal cancer cells and promoted the migration and invasion of cells. The proliferation of esophageal cancer cells increased in a dose-dependent manner with TGF- $\beta$ concentration. TGF- $\beta$ treatment induced high expression of miR-10b in both cell lines. The miR-10b mimic + TGF- $\beta$ group further promoted the migration and invasion of esophageal cancer cells. Western blot analysis determined that, compared with the control group, miR-10b mimic increased TGF- $\beta$ expression. miR-10b mimic also inhibited the expression
\end{abstract}

Correspondence to: Dr Shengli Gao, Department of Thoracic Surgery, Affiliated Tumor Hospital, Xinjiang Medical University, 789 Suzhou East Street, Xinshi, Urumqi, Xinjiang 830011, P.R. China E-mail: doctorliu_1981@sina.com

Professor Wei Zeng, Department of Hematology and Oncology, Shenzhen University General Hospital, 1098 Xueyuan Avenue, Nanshan, Shenzhen, Guangdong 518055, P.R. China

E-mail: 2406826341@qq.com

Key words: human esophageal cancer, microRNA-10b, transforming growth factor- $\beta$, phosphatase and tensin homolog, biological behavior of phosphatase and tensin homolog (PTEN) in tumor cells. Compared with the control group, TGF- $\beta$ inhibited the expression of PTEN with the miR-10b mimic + TGF- $\beta$ group further inhibiting the PTEN. miR-10b inhibitor + TGF- $\beta$ reversed the effect of TGF- $\beta$ and miR-10b on PTEN. In conclusion, miR-10b promoted cell cycle progression, inhibited apoptosis and promoted the migration and invasion of esophageal cancer cells. The mechanism may be related to the upregulation of TGF- $\beta$ and the downregulation of PTEN. The present findings suggested that miR-10b might be a potential therapeutic target for esophageal cancer.

\section{Introduction}

MicroRNAs (miRNAs) are a class of endogenous, non-coding, single-stranded small RNAs of 19-24 nucleotides in length. They inhibit target gene expression or translation at the post-transcriptional level by binding target RNAs, thus affecting cell proliferation, apoptosis or the cell cycle (1-3). miRNAs also participate in tumorigenesis and development, acting as oncogenes and tumor suppressor genes (4). miR-10b is involved in the invasion and metastasis of tumor cells. It has a crucial role in tumor cell proliferation, apoptosis, cell cycle or metastasis (5-7). miR-10b also serves an important role in the regulation of breast cancer metastasis (8). Therefore, it is speculated that miR-10b may be involved in tumor invasion and metastasis.

Esophageal cancer is one of the common tumors of the digestive tract and its incidence and mortality varies globally (9). China is a high-risk area for esophageal cancer due to carcinogen exposure and nutritional deficiency (10). It is reported that abnormal miRNA expression is present in the serum of patients with esophageal cancer (11).

The transforming growth factor- $\beta$ (TGF- $\beta$ ) signaling pathway is instrumental in mammalian development and in tumor suppression via inhibiting proliferation and inducing apoptosis in multiple cell types. However, TGF- $\beta$ has a dual role in tumor development as it can also promote tumor cell invasiveness and metastasis via regulating the immune system and tumor microenvironment $(12,13)$. Phosphatase and tensin homolog (PTEN) is a tumor suppressor gene, which regulates tumor cell invasion, metastasis and proliferation (14). PTEN may regulate PI3K signaling whilst a relationship between the PI3K pathway and cancer has been established (15). 
miR-10b is highly expressed in esophageal cancer tissues and plasma, and is associated with poor prognosis for patients with esophageal cancer $(11,16)$. However, the role and mechanism of miR-10b in esophageal cancer cells remains unclear. In the present study, the role and mechanism of miR-10b in esophageal cancer cells were investigated. Esophageal cancer cell lines TE-1 and EC9706 were transfected with miR-10b mimic and inhibitor to upregulate and downregulate miR-10b, respectively. The effect of miR-10b on TGF- $\beta$ and PTEN was also analyzed. The present findings may provide a theoretical basis for targeted therapy of esophageal cancer.

\section{Materials and methods}

Cell lines. Human esophageal cancer cell lines TE-1 (The Cell Bank of Type Culture Collection of Chinese Academy of Sciences) and EC9706 (The Cell Bank of Type Culture Collection of Chinese Academy of Sciences) were cultured in RPMI-1640 complete medium (HyClone; GE Healthcare Life Sciences) containing 10\% fetal calf serum (HyClone; GE Healthcare Life Sciences) and incubated in a $37^{\circ} \mathrm{C}, 5 \% \mathrm{CO}_{2}$ incubator.

Cell transfection and treatment. TE-1 cells and EC9706 cells were divided into the control group, non-targeting negative control (NC) group, miR-10b mimic group and miR-10b inhibitor group. The NC (sequence, 5'-TTCTCCGAACGT GTCACGT-3'; Beyotime Institute of Biotechnology), miR-10b mimic (sequence, 5'-UACCCUGUAGAACCGAAUUUG UG-3'; 100 nmol/1; Beyotime Institute of Biotechnology) and inhibitor (sequence, 5'-AUGGGACAUCUUGGCUUAAAC AC-3'; 100 nmol/1; Beyotime Institute of Biotechnology) were transfected with Lipofectamine ${ }^{\circledR} 2000$ (Gibco; Thermo Fisher Scientific, Inc.) at $37^{\circ} \mathrm{C}$. Cells in the control group were not transfected. The transfection time was determined based on pilot experiments. At $24 \mathrm{~h}$ following transfection, subsequent experiments were performed.

For growth factor experiments, TE-1 cells were divided into the control group, TGF- $\beta$ group, $\mathrm{miR}-10 \mathrm{~b}$ mimic + TGF- $\beta$ group and miR-10b inhibitor + TGF- $\beta$ group. Cells were transfected with miR-10b mimic and miR-10b inhibitor as described above. At the same time, cells were incubated with TGF- $\beta$ (10 ng/ml; PeproTech EC, Ltd.) for 48-h.

For analyzing the effect of TGF- $\beta$ on cell proliferation, TE- 1 cells were treated with different concentrations of TGF- $\beta$ $(0,1.25,2.5,5$ and $10 \mathrm{ng} / \mathrm{ml})$ for 12,24 and $48 \mathrm{~h}$.

Flow cytometry. Following $48 \mathrm{~h}$ of transfection, cells were collected by centrifugation at $800 \mathrm{x} \mathrm{g}$ and $4^{\circ} \mathrm{C}$ for $5 \mathrm{~min}$. Cell apoptosis was detected with an Annexin V-fluorescein isothiocyanate (FITC)/propidium iodide (PI) apoptosis kit (Sigma-Aldrich; Merck KGaA). In brief, cells were stained with $5 \mu \mathrm{l}$ Annexin V-FITC and $5 \mu \mathrm{l}$ PI in the dark at $4^{\circ} \mathrm{C}$ for $30 \mathrm{~min}$. After adding the Binding Buffer Sigma-Aldrich (Merck KGaA), cells were analyzed on a flow cytometer (Beckman Coulter, Inc.). The apoptosis rate was calculated as the sum of the early apoptosis rate and late apoptosis rate.

For cell cycle analysis, cells were incubated with $400 \mu \mathrm{l}$ of PI (50 $\mu \mathrm{g} / \mathrm{ml})$ (Sigma-Aldrich; Merck KGaA) for 30-60 min at $4^{\circ} \mathrm{C}$. Flow cytometry was used to measure the proportion of cells in each cell cycle.

Transwell invasion and migration assays. The invasion assay was performed using Transwell chamber with $8 \mu \mathrm{m}$ pores (Corning Inc.). Briefly, $50 \mu \mathrm{l}$ of diluted Matrigel ( $2 \mathrm{mg} / \mathrm{ml}$, BD Biosciences) was placed on the inner surface of the chamber and incubated at $37^{\circ} \mathrm{C}$ for $30 \mathrm{~min}$. Cells were transfected for $24 \mathrm{~h}$ and seeded in the top chamber. Culture medium supplemented with $10 \%$ fetal bovine serum was then added to the bottom chamber. Following 24-h incubation, non-invading cells were removed from the top of the Matrigel with a cotton-tipped swab. Invading cells at the bottom of the Matrigel were fixed using $70 \%$ methanol at $37^{\circ} \mathrm{C}$ for $30 \mathrm{~min}$ and stained with $0.1 \%$ crystal violet at room temperature for $10 \mathrm{~min}$. The invasion efficiency was determined by counting the penetrated cells under Olympus IX73 (Olympus Corporation) at x200 magnification in 5 random fields per well. Each experiment was performed in triplicate.

The protocol of Transwell migration assay was similar to the invasion assays except that no Matrigel was used on the inner surface of the chamber.

MTT assay. Following TGF- $\beta$ treatment for 12, 24 and $48 \mathrm{~h}$, the culture supernatant was removed and $90 \mu \mathrm{l}$ of fresh medium was added. Following this, $10 \mu \mathrm{l}$ of MTT solution (Sigma-Aldrich; Merck KGaA) was added and incubated at $37^{\circ} \mathrm{C}$ for $4 \mathrm{~h}$. Next, $110 \mu \mathrm{l}$ of DMSO was added and then samples were shaken for $10 \mathrm{~min}$ at low speed to fully dissolve the crystals. The absorbance was measured at $450 \mathrm{~nm}$ on a microplate reader (Thermo Fisher Scientific, Inc.).

EdU assay. EdU assay was performed using an EdU assay kit from Guangzhou RiboBio Co., Ltd. In brief, $24 \mathrm{~h}$ following transfection, cells $\left(4 \times 10^{3}\right)$ were seeded into 96 -well plates. Following incubation at $37^{\circ} \mathrm{C}$ for $24 \mathrm{~h}, 50 \mu \mathrm{M}$ EdU solution was added to each well, which was then incubated at $37^{\circ} \mathrm{C}$ for 2 h. Cells were then washed, fixed and stained with Apollo ${ }^{R}$ Fluorescent dye solution (Guangzhou RiboBio Co., Ltd). Three fields were randomly selected and then imaged using a fluorescence microscope (x400) (Olympus IX73; Olympus Corporation). Cells with green fluorescence were considered positive. ImageJ software v1.8 (National Institutes of Health) was used for cell counting. The relative EdU incorporation rate was then calculated as number of cells with green fluorescence/total cell number $(100 \%)$.

Reverse transcription-quantitative PCR (RT-qPCR). Total RNA was extracted from cells by TRIzol (Invitrogen; Thermo Fisher Scientific, Inc.) and subjected to reverse transcription with a PrimeScript ${ }^{\mathrm{TM}} \mathrm{RT}$ reagent kit (Takara Bio, Inc.) at $42^{\circ} \mathrm{C}$ for $50 \mathrm{~min}$. The prepared cDNA was subjected to PCR amplification with SYBR Green PCR kit (KAPA Biosystems; Roche Diagnostics). Primer sequences were as follows: miR-10b forward, 5'-GGG TACCCTGTAGAACCG-3' and reverse, 5'-AACTGGTGTCGT GGAGTCGGC-3' and U6 forward, 5'-CTCGCTTCGGCAGCA CATATACT-3' and reverse, 5'-ACGCTTCACGAATTTGCG TGT-3'. Thermocycling conditions were as follows: $95^{\circ} \mathrm{C}$ for $3 \mathrm{~min}, 95^{\circ} \mathrm{C}$ for $5 \mathrm{sec}, 56^{\circ} \mathrm{C}$ for $10 \mathrm{sec}, 72^{\circ} \mathrm{C}$ for $25 \mathrm{sec}, 39$ cycles of $65^{\circ} \mathrm{C}$ for $5 \mathrm{sec}$ and $95^{\circ} \mathrm{C}$ for $50 \mathrm{sec}$. The $2^{-\Delta \Delta \mathrm{Cq}}$ method was used to calculate the relative expression (17). 
A

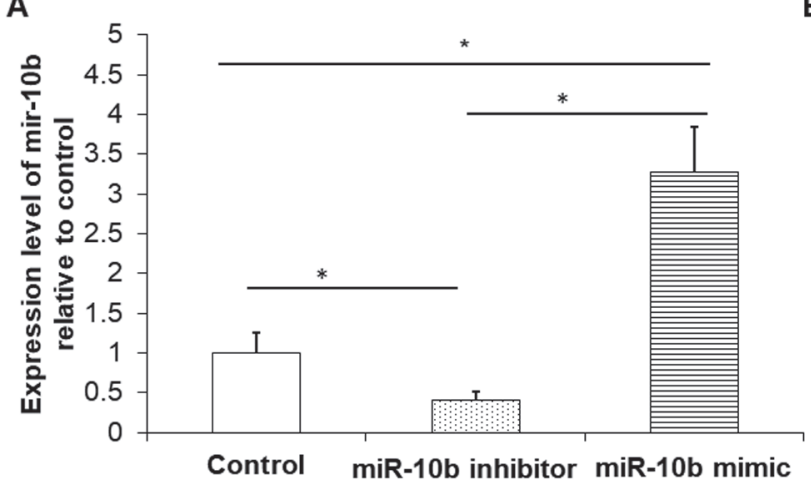

B

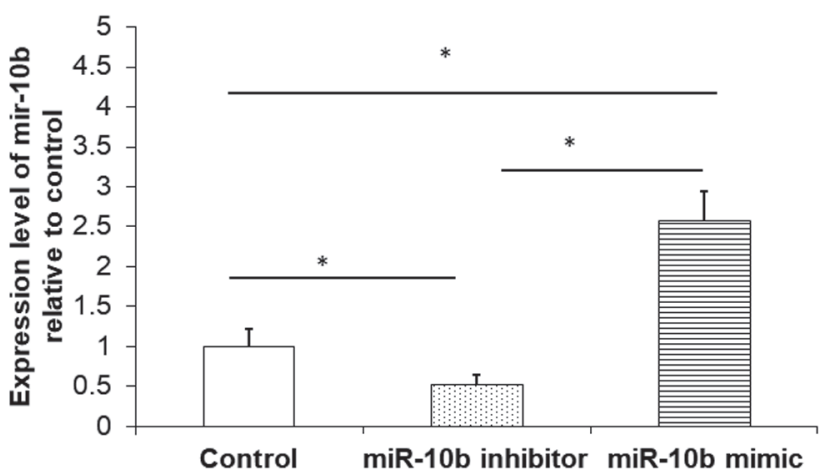

Figure 1. miR-10b mimic upregulates and miR-10b inhibitor downregulates miR-10b expression. (A) TE-1 and (B) EC9706 cells were divided into control group, miR-10b mimic group and miR-10b inhibitor group then the expression levels of miR-10b were detected by reverse transcription-quantitative PCR. ${ }^{*} \mathrm{P}<0.05$ as indicated. miR, microRNA.

Western blot analysis. Protein extraction followed standard methods using radioimmunoprecipitation assay Lysis and Extraction Buffer (Thermo Fisher Scientific). The protein was quantified using bicinchoninic acid kit (Thermo Fisher Scientific, Inc.). Proteins ( $20 \mu \mathrm{g}$ per lane) were electrophoresis on $12 \%$ SDS-PAGE and then transferred onto polyvinylidene difluoride membrane. After blocking with 5\% non-fat milk at room temperature for $1 \mathrm{~h}$, membranes were incubated with primary antibodies against TGF- $\beta$ (Abcam; cat. no. ab31013; 1:1,000), PTEN (Abcam; cat. no. ab32199; 1:1,000), and $\beta$-actin (Cell Signaling Technology, Inc.; cat. no. 4970L; 1:1,000) overnight at room temperature or overnight at $4^{\circ} \mathrm{C}$. Following washing, membranes were incubated with horseradish peroxidase-labeled secondary antibody (Thermo Fisher Scientific, Inc.; cat. no. 31430; 1:5,000) for $1 \mathrm{~h}$ at room temperature. The protein bands were visualized with enhanced chemiluminescence (Bio-Rad Laboratories, Inc.). The ratio of each band was analyzed with a fully automated chemiluminescence analyzer (Chemiluminescence Imaging System; Clinx Science Instruments Co. Ltd.).

Statistical analysis. Data were analyzed using statistical software SPSS 19.0 (IBM Corp). Data were expressed as mean \pm standard deviation. One-way analysis of variance was used to compare the differences amongst multiple groups, followed by Student-Newman-Keuls test. $\mathrm{P}<0.05$ was considered to indicate statistical significance.

\section{Results}

miR-10b mimic upregulates and miR-10b inhibitor downregulates miR-10b expression, respectively. RT-qPCR was used to detect the relative expression of miR-10b. Results demonstrated that, compared with the control group, miR-10b inhibitor effectively silenced the expression of miR-10b in TE-1 cells (Fig. 1A) and EC9706 cells (Fig. 1B). Compared with the control group, miR-10b mimic significantly increased the relative expression of miR-10b in both TE-1 cells (Fig. 1A) and EC9706 cells (Fig. 1B). These experiments demonstrated successful transfection efficiency.

miR-10b increases proliferation of esophageal cancer cells. To determine the effect of miR-10b on cell viability of esophageal cancer cells, the MTT assay was performed. Cell viability of TE-1 cells in the miR-10b mimic group at $72 \mathrm{~h}$ was significantly higher than the NC group and control group (Fig. 2A). There was no significant difference between the NC and control groups. Similar results were also observed in EC9706 cells (Fig. 2A). To further confirm proliferation results, the EdU assay was conducted. The relative EdU incorporation rate in the miR-10b inhibitor group was significantly lower than in the control group for both TE-1 and EC9706 cells (Fig. 2B). These results indicated that miR-10b promoted the proliferation of esophageal cancer cells.

miR-10b mimic decreases esophageal cancer cell apoptosis and promotes cell cycle progression whilst miR-10b inhibitor has the reverse effect. Flow cytometry was used to detect the changes of apoptosis in the three groups following transfection. Results demonstrated that, compared with control group, miR-10b inhibitor promoted cell apoptosis (Fig. 3A and B) and arrested the cell cycle at the $S$ phase and $\mathrm{G}_{2} / \mathrm{M}$ phase (Fig. 4A and $\mathrm{B}$ ), indicating that miR-10b downregulation inhibited esophageal cancer cell cycle progression and promoted apoptosis. By contrast, miR-10b mimic inhibited apoptosis (Fig. 3A and $\mathrm{B})$ and promoted cell cycle progression compared with miR-10b inhibitor (Fig. 4A and B).

miR-10b inhibitor decreases migration and invasion of esophageal cancer cells whilst miR $10 \mathrm{~b}$ mimic has the reverse effect. In order to investigate the effect of miR-10b mimic or miR-10b inhibitor on the migration and invasion ability of esophageal cancer cells, the Transwell assay was performed. Compared with the control group, esophageal cancer cells transfected with miR-10b mimic significantly promoted the migration and invasion of esophageal cancer cells (Fig. 5A and B). Esophageal cancer cells transfected with miR-10b inhibitor significantly inhibited esophageal cancer cell migration and invasion compared with the miR-10b mimic group and the control group (Fig. 5A and B).

TGF- $\beta$ treatment increases the proliferation of the human esophageal cancer cell line TE-1. The proliferation of esophageal cancer cells under different concentrations of TGF- $\beta$ was detected with MTT assay. As demonstrated in Table I, within 
A

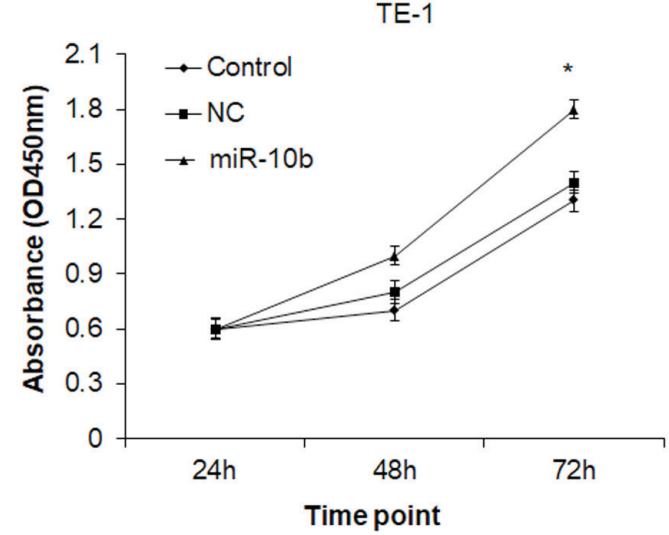

B
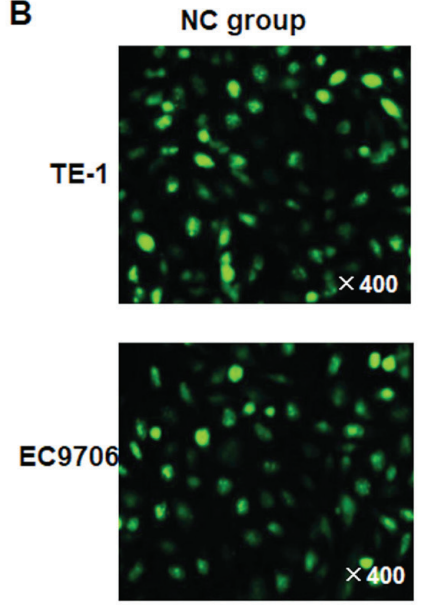

miR-10b inhibitor group
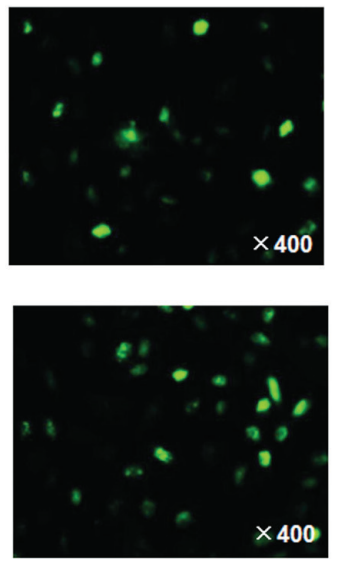

EC9706

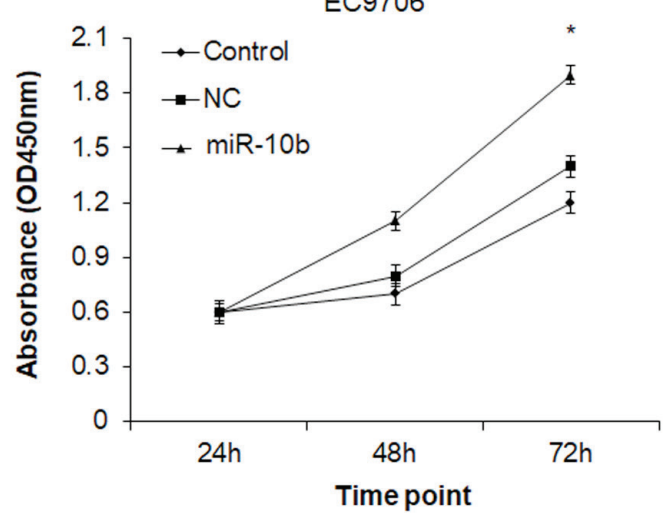

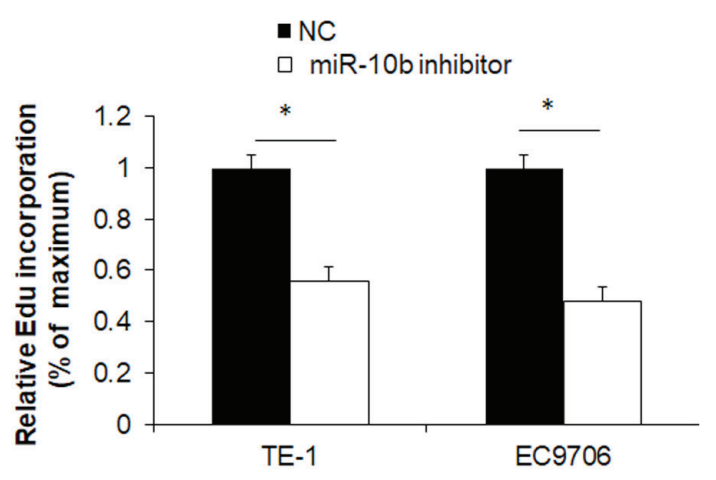

Figure 2. miR-10b increases proliferation of esophageal cancer cells. (A) MTT was used to detect the cell viability of TE-1 and EC9706 cells in control group, NC group, miR-10b mimic group or miR-10b inhibitor. (B) EdU assay was performed to analyze cell proliferation and the relative EdU incorporation rate was calculated (magnification, $\mathrm{x} 400$ ). ${ }^{*} \mathrm{P}<0.05$ vs. control or NC. miR, microRNA; NC, negative control.

12-h, the proliferation of esophageal cancer cells increased in a TGF- $\beta$ dose dependent manner. The proliferation of esophageal cancer cells increased significantly with the increase of TGF- $\beta$ concentration. Within 48 -h of culture, the proliferation of esophageal cancer cells was significantly increased with the increase in TGF- $\beta$ concentration. Thus, for subsequent experiments, $10 \mathrm{ng} / \mathrm{ml}$ concentration of TGF- $\beta$ was selected.

TGF- $\beta$ increases miR-10b expression. TE-1 and EC9706 cells were treated with $10 \mathrm{ng} / \mathrm{ml} \mathrm{TGF}-\beta$ for $48 \mathrm{~h}$ and miR-10b expression was detected with RT-qPCR. miR-10b expression was significantly increased in the TGF- $\beta$ group compared with the control group (Fig. 6), indicating that TGF- $\beta$ induced the expression of miR-10b.

TGF- $\beta$ promotes migration and invasion of esophageal cancer cells. Results demonstrated that TGF- $\beta$ alone could promote the migration and invasion of esophageal cancer cells compared with the control group (Fig. 7A and B). The miR-10b mimic + TGF- $\beta$ group exhibited increased esophageal cancer cell migration and invasion ability compared with the miR-10b inhibitor + TGF- $\beta$ group. Results indicated that upregulation of miR-10b expression worked synergistically with TGF- $\beta$ to enhance the migration and invasion ability of esophageal cancer cells.
TGF- $\beta$ promotes cell proliferation and reduces apoptosis of esophageal cancer cells. MTT results demonstrated that TGF- $\beta$ alone promoted the proliferation of esophageal cancer cells compared with the control group (Fig. 8A). However, miR-10b inhibitor decreased the proliferation ability of esophageal cancer cells compared with the control group. There was no significant difference in proliferation between the miR-10b inhibitor + TGF- $\beta$ and control group. These findings indicated that knocking down miR-10b expression in TE-1 cells decreased the ability of TGF- $\beta$ to promote cell proliferation.

Flow cytometry determined that the apoptosis (early apoptosis + late apoptosis) rate in the miR-10b inhibitor group and miR-10b inhibitor + TGF- $\beta$ group was significantly increased, whereas the TGF- $\beta$ group was significantly decreased compared with the control group (Fig. 8B and C). The apoptosis rate in each group in descending order was as follows: miR-10b inhibitor group $>$ miR-10b inhibitor + TGF- $\beta$ group $>$ control group $>$ TGF- $\beta$ group. Therefore, TGF- $\beta$ treatment attenuated the inhibitory effect of miR-10b inhibitor on cell apoptosis.

miR $-10 b$ regulates the expression of TGF- $\beta$ and PTEN. To detect the expression of TGF- $\beta$ and PTEN following miR-10b transfection, western blot analysis was performed. miR-10b inhibitor downregulated the expression of TGF- $\beta$ whereas miR-10b mimic upregulated its expression in esophageal 
A

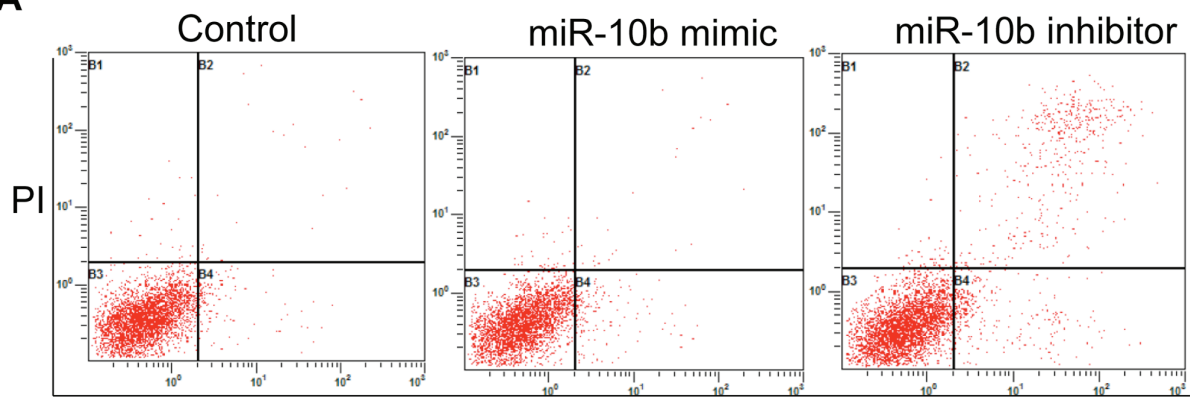

Annexin V

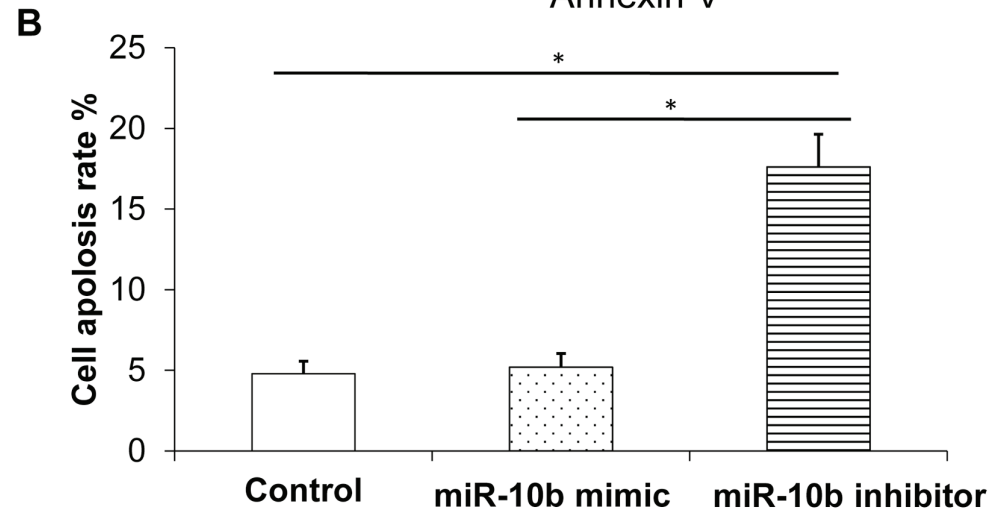

Figure 3. miR-10b mimic decreases TE-1 esophageal cancer cell apoptosis whilst miR-10b inhibitor has the reverse effect. (A) Representative flow cytometry results of control group, miR-10b mimic group and miR-10b inhibitor group. (B) Comparison of apoptosis rate amongst the three groups. " $\mathrm{P}<0.05$ as indicated. miR, microRNA; PI, propidium iodide.

A

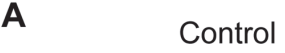

miR-10b mimic

miR-10b inhibitor

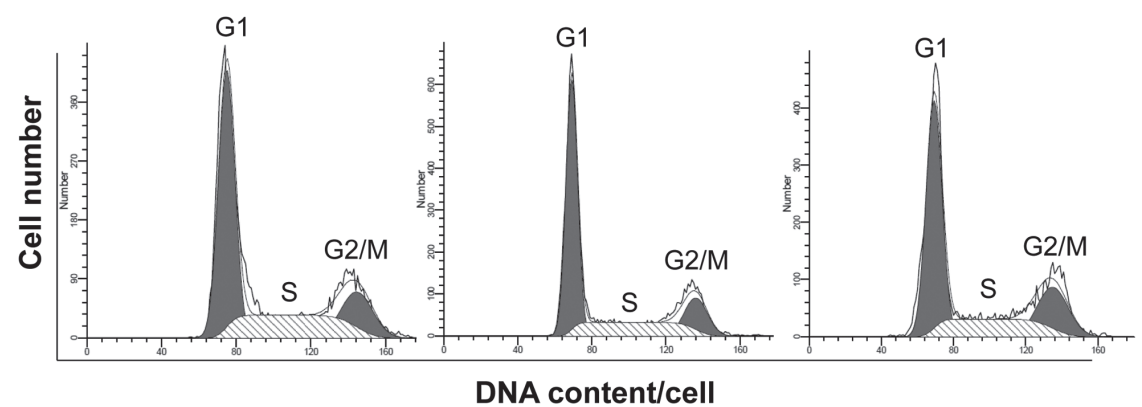

B

$\square$ Control

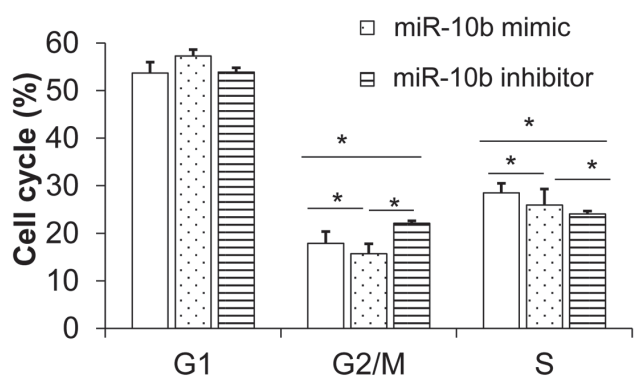

Figure 4. miR-10b mimic promotes cell cycle progression whilst miR-10b inhibitor has the reverse effect. (A) Representative flow cytometry results of control group, miR-10b mimic group and miR-10b inhibitor group. (B) Comparison of cell cycle distribution amongst three groups. "P<0.05 as indicated. miR, microRNA.

cancer cells, indicating that miR-10b regulates the expression of TGF- $\beta$ in esophageal cancer cells (Fig. 9A).

PTEN is a tumor suppressor gene that has an important regulatory role in cell proliferation and apoptosis (18). PTEN is the target gene of miR-10b (19). Western blot analysis demonstrated that miR-10b mimic inhibited PTEN expression in tumor cells and miR-10b inhibitor promoted PTEN expression (Fig. 9A). 
A

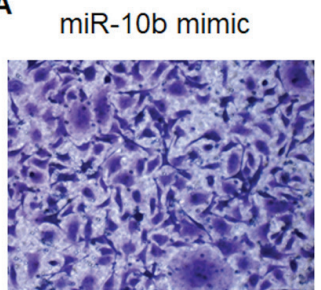

B

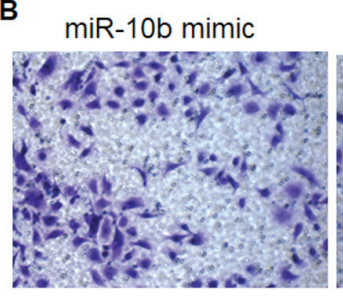

miR-10b inhibitor

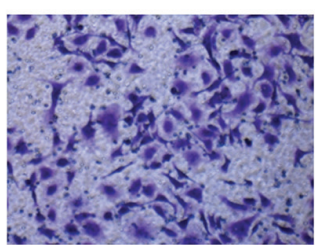

miR-10b inhibitor

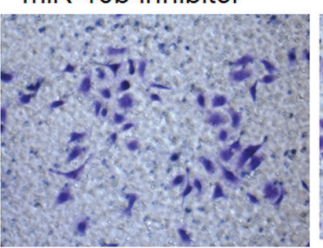

Control

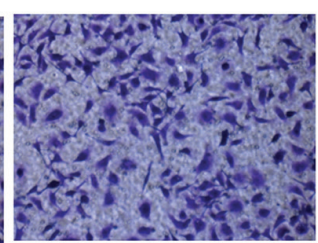

Control

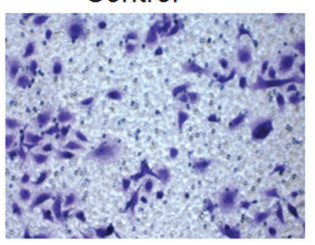

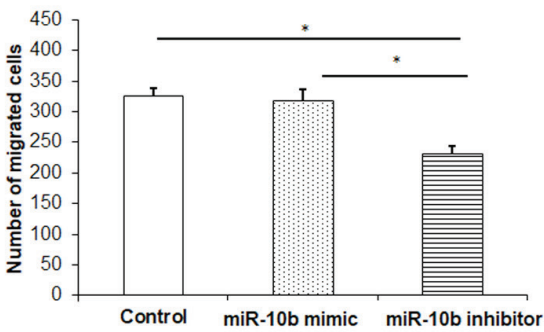

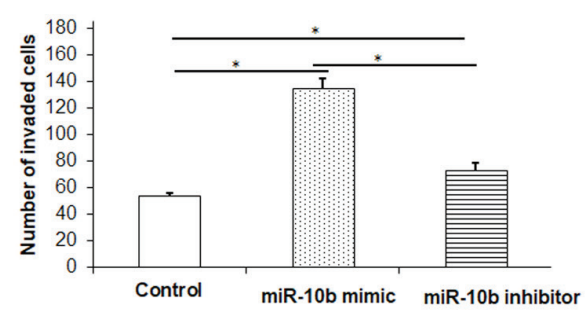

Figure 5. miR-10b inhibitor decreases migration and invasion of esophageal cancer cells whilst miR10b mimic has the reverse effect. (A) Transwell migration assay was used to detect the effects of miR-10b mimic or inhibitor on the migration and (B) invasion of esophageal cancer cells (magnification, $\mathrm{x} 200$ ). ${ }^{*} \mathrm{P}<0.05$ as indicated. miR, microRNA.

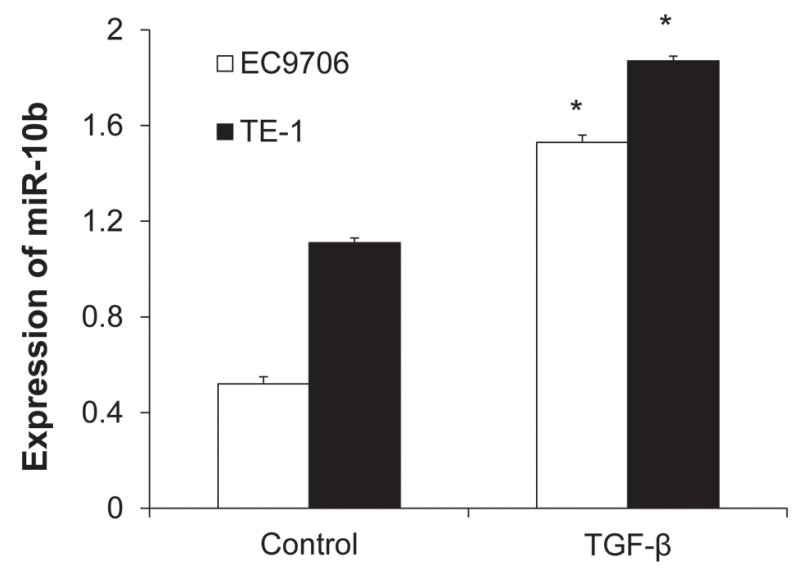

Figure 6. TGF- $\beta$ increases miR-10b expression. TE-1 and EC9706 cells were incubated with $10 \mathrm{ng} / \mathrm{ml} \mathrm{TGF}-\beta$ for $48 \mathrm{~h}$ then, miR-10b expression was detected with reverse transcription-quantitative PCR. "P<0.05 vs. control. TGF- $\beta$, transforming growth factor- $\beta ;$ miR, microRNA.

The relationship between miR-10b, TGF- $\beta$ and PTEN was further investigated. In vitro experiments identified that, compared with the control group, TGF- $\beta$-treated esophageal cancer cells inhibited the expression of PTEN. miR-10b mimic + TGF- $\beta$ group exhibited a greater decrease in the expression of PTEN. Furthermore, the miR-10b inhibitor + TGF- $\beta$ group exhibited increased PTEN expression compared with miR-10b mimic + TGF- $\beta$ group (Fig. 9B).

\section{Discussion}

miR-10b has varying roles in different cellular backgrounds or tumor microenvironments $(20,21)$. For example, miR-10b promotes tumor invasion and metastasis in breast and esophageal cancers and is therefore known as a pro-metastatic factor (22). By contrast, miR-10b has a tumor-suppressive role in clear-cell renal cell carcinoma (23). Therefore, miR-10b may be involved in the process of tumorigenesis and development.
Further study on the role of miR-10b in tumorigenesis and its mechanism may provide experimental evidence for the clinical diagnosis and treatment of tumors. The present study demonstrated that miR-10b promoted cell proliferation. Inhibition of miR1-10b arrested the cell cycle at $S$ and $\mathrm{G}_{2} / \mathrm{M}$ phase, suggesting that miR-10b promoted cell cycle progression. Furthermore, miR-10b inhibited apoptosis and promoted tumor cell migration and invasion, which is consistent with the role of miR-10b in breast cancer and hepatocellular carcinoma $(24,25)$.

TGF- $\beta$ has an important role in cell proliferation, differentiation, survival and apoptosis $(26,27)$. It also induces epithelial-mesenchymal transition by activating other signaling pathways (28). In tumors, TGF- $\beta$, once activated, promotes cell growth, migration and invasion $(29,30)$, therefore, the level of TGF- $\beta$ expression in tumors is also related to the degree of malignancy of the tumor. A previous study demonstrated that TGF- $\beta$ promotes the migration of human glioma cells by promoting the expression of miR-10b (31). In the present study, it was demonstrated that the proliferation of esophageal cancer cells increased along with an increase of TGF- $\beta$ concentration. TGF- $\beta$ induced the high expression of miR-10b in esophageal cancer cells. miR-10b also promotes the expression of TGF- $\beta$ and invasion of pancreatic cancer cells (32). These results indicated that TGF- $\beta$ is related to miR-10b. miRNA not only mediates the role of the TGF- $\beta /$ Smad signaling pathway in tumors, but also has a role in promoting or suppressing tumor progression by regulating important members of the TGF- $\beta /$ Smad signaling pathway (33). The present study determined that upregulation of miR-10b expression by miR-10b mimic enhanced the migration and invasion ability of esophageal cancer cells and further upregulated the expression of TGF- $\beta$ in esophageal cancer cells. These results indicated that miR-10b promoted the expression of TGF- $\beta$ in tumor cells and serves a crucial role in the occurrence and development of esophageal cancer. These findings may be an important basis for the use of miR-10b as a new target for cancer therapy. 
Table I. Effects of different doses of TGF- $\beta$ on the proliferation of TE- 1 cells at $450 \mathrm{~nm}$.

\begin{tabular}{|c|c|c|c|c|c|}
\hline \multirow[b]{2}{*}{ Group } & \multicolumn{5}{|c|}{ TGF- $\beta(\mathrm{ng} / \mathrm{ml})$} \\
\hline & 0 & 1.25 & 2.5 & 5 & 10 \\
\hline $12-\mathrm{h}$ & $0.362 \pm 0.003$ & $0.398 \pm 0.002^{\mathrm{a}}$ & $0.409 \pm 0.002^{\mathrm{a}}$ & $0.435 \pm 0.007^{\mathrm{a}, \mathrm{b}}$ & $0.451 \pm 0.003^{\mathrm{a}-\mathrm{c}}$ \\
\hline 24-h & $0.435 \pm 0.006^{\mathrm{e}}$ & $0.546 \pm 0.007^{\mathrm{a}, \mathrm{e}}$ & $0.614 \pm 0.006^{\mathrm{a}, \mathrm{b}, \mathrm{e}}$ & $0.755 \pm 0.007^{\mathrm{a}-\mathrm{c}, \mathrm{e}}$ & $0.816 \pm 0.006^{\mathrm{a}-\mathrm{e}}$ \\
\hline 48-h & $0.513 \pm 0.006^{\mathrm{e}, \mathrm{f}}$ & $0.670 \pm 0.005^{\mathrm{a}, \mathrm{e}, \mathrm{f}}$ & $0.788 \pm 0.002^{\mathrm{a}-\mathrm{b}, \mathrm{e}, \mathrm{f}}$ & $0.925 \pm 0.007^{\mathrm{a}-\mathrm{c}, \mathrm{e}, \mathrm{f}}$ & $1.010 \pm 0.029^{\mathrm{a}-\mathrm{d}, \mathrm{f}}$ \\
\hline
\end{tabular}

${ }^{\mathrm{a}} \mathrm{P}<0.05$ vs. $0 \mathrm{ng} / \mathrm{ml} ;{ }^{\mathrm{b}} \mathrm{P}<0.05$ vs. $1.25 \mathrm{ng} / \mathrm{ml} ;{ }^{\mathrm{c}} \mathrm{P}<0.05$ vs. $2.5 \mathrm{ng} / \mathrm{ml} ;{ }^{\mathrm{d}} \mathrm{P}<0.05$ vs. $5 \mathrm{ng} / \mathrm{ml} ;{ }^{\mathrm{e}} \mathrm{P}<0.05$ vs. $12-\mathrm{h}$; ${ }^{\mathrm{f}} \mathrm{P}<0.05$ vs. $24-\mathrm{h}$.

A
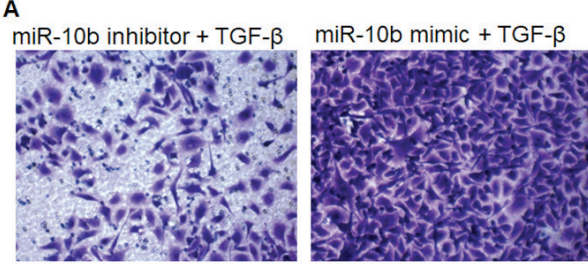

TGF- $\beta$
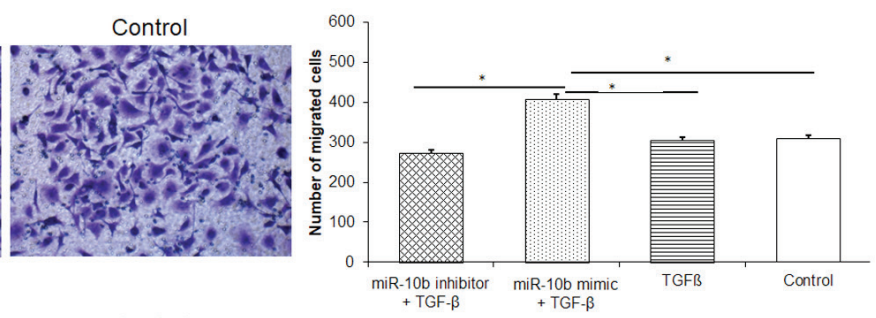

B
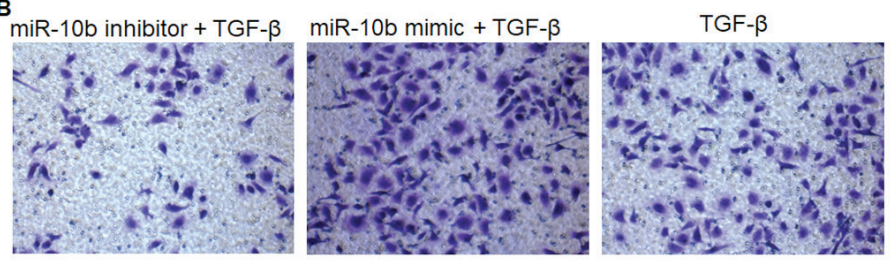

Control
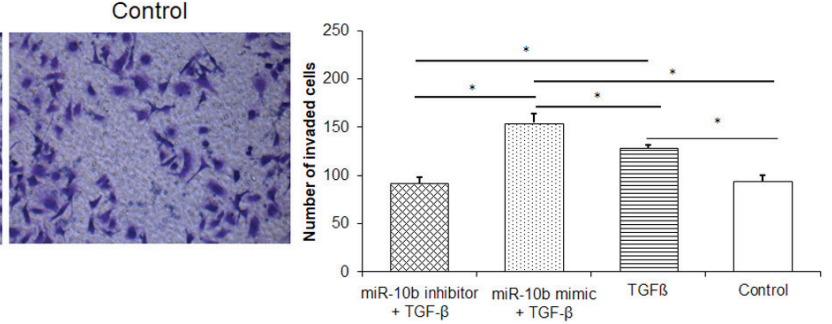

Figure 7. TGF- $\beta$ promotes invasion of esophageal cancer cells. (A) Transwell assay was used to detect the migration and (B) invasion of esophageal cancer cells in control group, TGF- $\beta$, miR-10b mimic + TGF- $\beta$ group and miR-10b inhibitor + TGF- $\beta$ group (magnification, $x 200$ ). ${ }^{*} \mathrm{P}<0.05$ with comparisons indicated by lines. TGF- $\beta$, transforming growth factor- $\beta$; miR, microRNA.

A

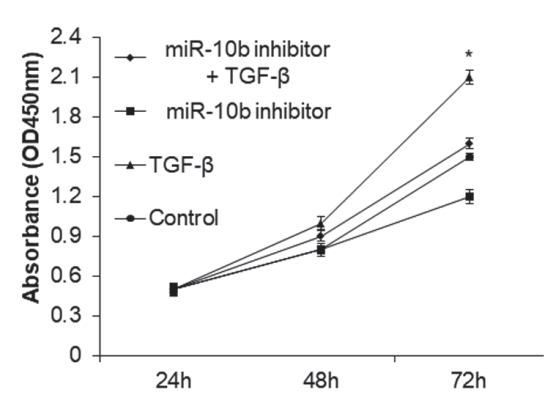

B

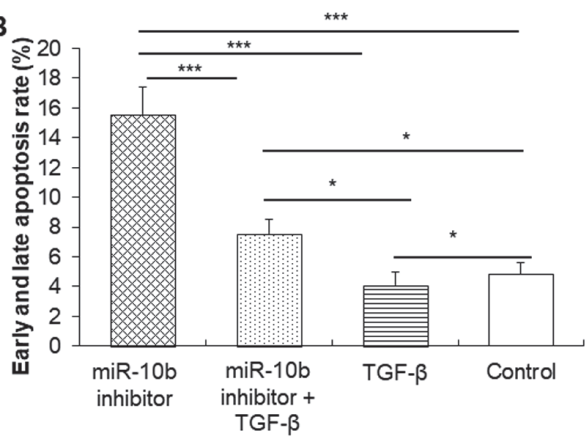

C

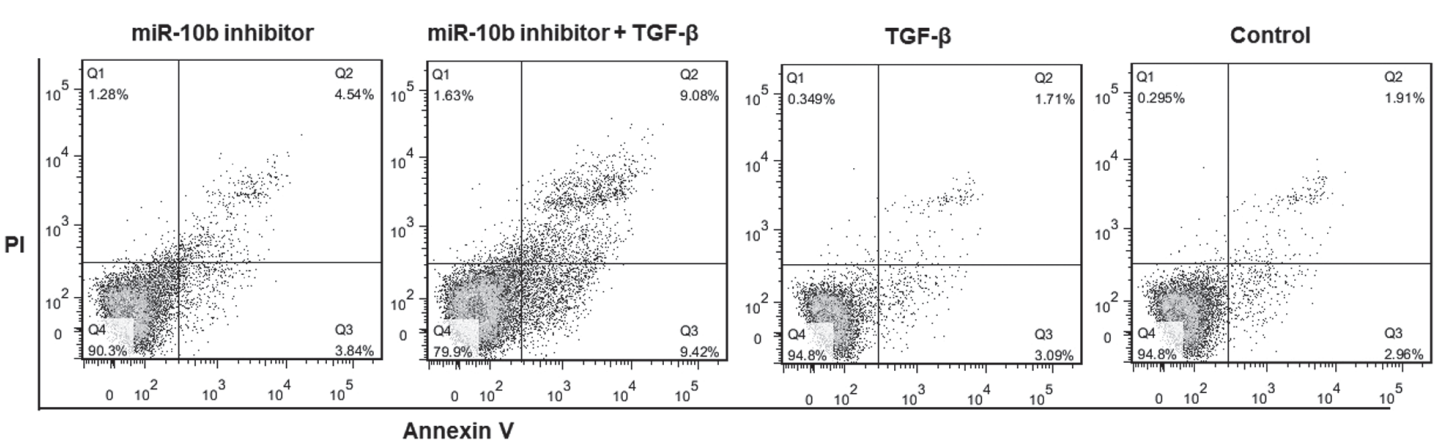

Figure 8. TGF- $\beta$ promotes cell proliferation and reduces apoptosis of esophageal cancer cells. (A) MTT was used to detect the proliferation of esophageal cancer cells. ${ }^{*} \mathrm{P}<0.05$ vs. control. (B) Cell apoptosis was analyzed by flow cytometry with the sum of the early and late apoptosis calculated as the apoptosis rate. ${ }^{*} \mathrm{P}<0.05$ and ${ }^{* * *} \mathrm{P}<0.001$ with comparisons indicated by lines. (C) Representative flow cytometry results of apoptosis with the percentage of cells in each quadrant presented. TGF- $\beta$, transforming growth factor- $\beta$; miR, microRNA. 
A

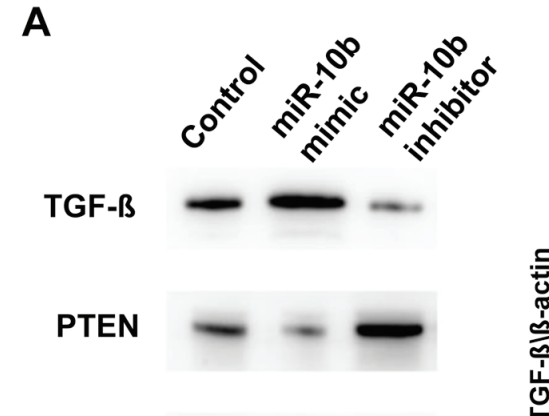

B-actin

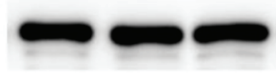

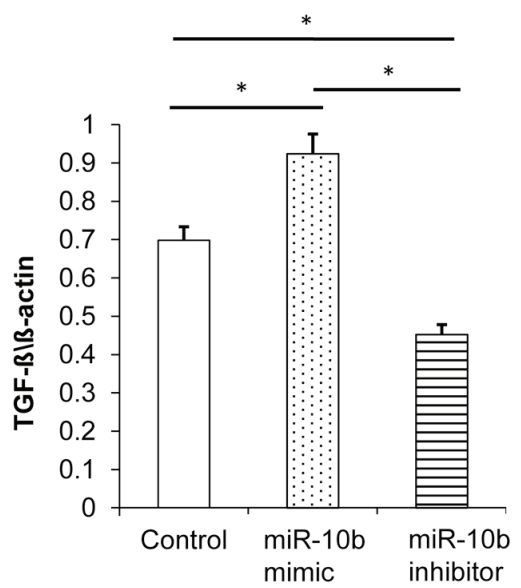

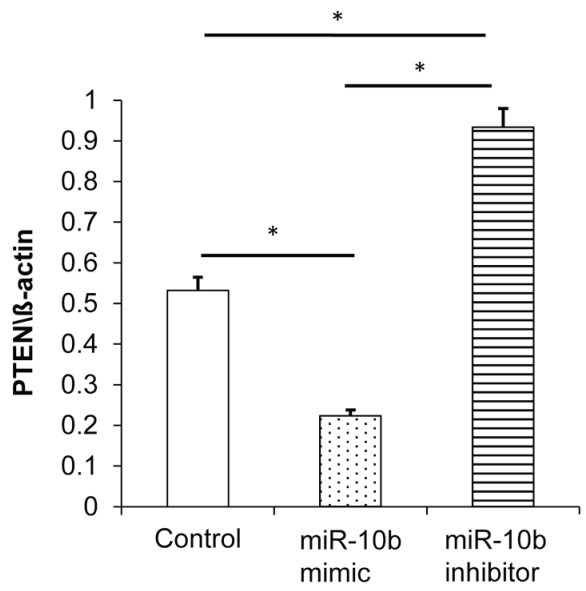

B
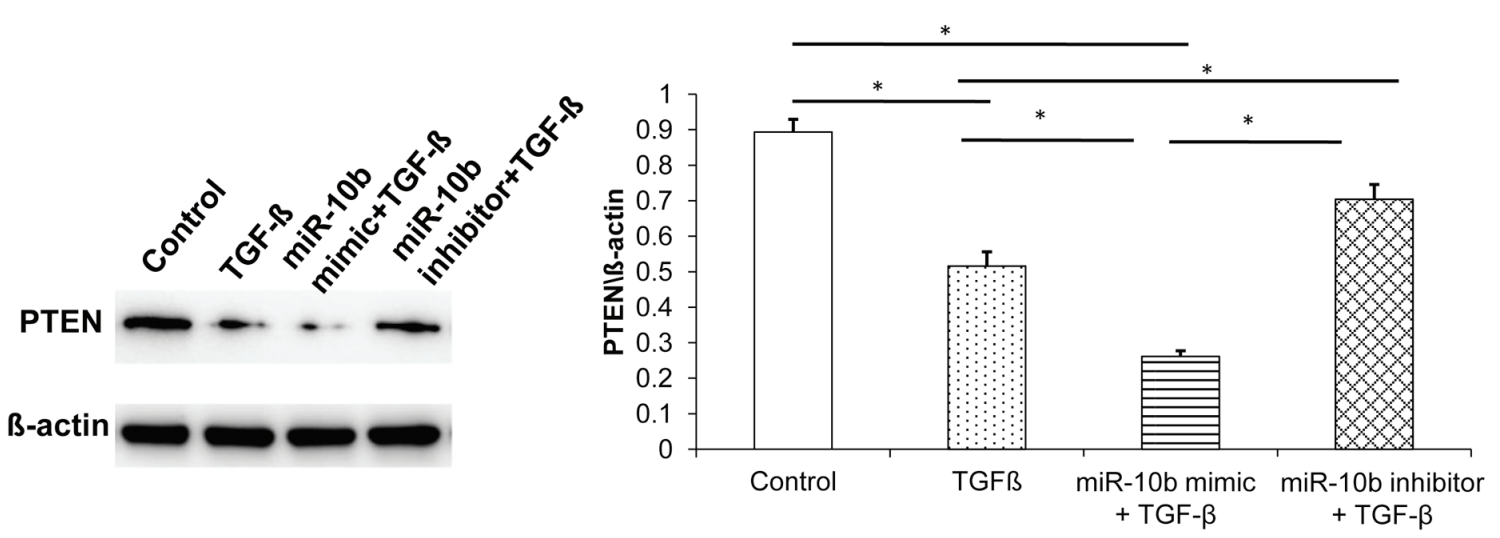

Figure 9. miR-10b regulates the expression of TGF- $\beta$ and PTEN. (A) Cells were divided into the control group, miR-10b mimic group and miR-10b inhibitor group and western blot analysis was used to detect protein expression. (B) Cells were divided into control group, TGF- $\beta$, miR-10b mimic + TGF- $\beta$ group and miR-10b inhibitor + TGF- $\beta$ group and PTEN levels were detected. ${ }^{*} \mathrm{P}<0.05$ with comparisons indicated by lines. miR, microRNA; TGF- $\beta$, transforming growth factor- $\beta$; PTEN, phosphatase and tensin homolog.

The tumor suppressor protein PTEN can be regulated by a variety of miRNAs. For example, miR-121 promotes tumor cell proliferation, migration and invasion by targeting PTEN protein (34). miR-10b can also target PTEN to promote human glioma cell migration and invasion $(5,35)$. This present study demonstrated that upregulation of miR-10b expression inhibited the expression of PTEN in tumor cells, whilst TGF- $\beta$ also inhibited the expression of PTEN. miR-10b overexpression together with TGF- $\beta$ treatment further inhibited PTEN expression, which may have further enhanced the promotion effect of miR-10b on the migration and invasion ability of esophageal cancer cells.

The present study has some limitations. For example, due to limited time and materials, all experiments were not performed with both cell lines, which warrants further study.

In summary, the present study demonstrated that miR-10b promoted the invasion and metastasis of esophageal cancer cells and has an important role in the occurrence and development of esophageal cancer. TGF- $\beta$ treatment induced high expression of miR-10b with miR-10b overexpression also promoting high TGF- $\beta$ protein expression. miR-10b + TGF- $\beta$ treatment synergistically enhanced the invasion and metastasis ability of esophageal cancer cells. The underlying mechanism might be via the inhibition of PTEN expression. In the future, miR-10b may be used as a potential target for the treatment of human esophageal cancer.

\section{Acknowledgements}

The authors would like to thank the Department of Thoracic Surgery, Affiliated Tumor Hospital of Xinjiang Medical University, Institute of Cancer Prevention and Treatment of Affiliated Tumor Hospital of Xinjiang Medical University and Department of Cardiothoracic Surgery, Shenzhen University General Hospital for their techical support.

\section{Funding}

This study was supported by the Natural Science Foundation of Xinjiang Uygur Autonomous Region (grant no. 2016D01C351).

\section{Availability of data and materials}

The datasets used and analyzed during the current study are available from the corresponding author on reasonable request.

\section{Authors' contributions}

YL performed all the experiments and wrote, edited and reviewed the manuscript. WZ performed the literature research and data analysis. AS and DH provided help in flow cytometry 
analysis. SG designed the study and reviewed the manuscript. All authors read and approved the final manuscript.

\section{Ethics approval and consent to participate}

Not applicable.

\section{Patient consent for publication}

Not applicable.

\section{Competing interests}

The authors declare that they have no competing interests.

\section{References}

1. Stappert L, Roese-Koerner B and Brustle O: The role of microRNAs in human neural stem cells, neuronal differentiation and subtype specification. Cell Tissue Res 359: 47-64, 2015.

2. Villegas-Ruiz V, Juárez-Méndez S, Pérez-González OA, Arreola H, Paniagua-García L, Parra-Melquiadez M, Peralta-Rodríguez R, López-Romero R, Monroy-García A, Mantilla-Morales A, et al: Heterogeneity of microRNAs expression in cervical cancer cells: Over-expression of miR-196a. Int J Clin Exp Pathol 7: 1389-1401, 2014.

3. Ye JJ and Cao J: MicroRNAs in colorectal cancer as markers and targets: Recent advances. World J Gastroenterol 20: 4288-4299, 2014.

4. He B, Yin B, Wang B, Xia Z, Chen C and Tang J: MicroRNAs in esophageal cancer (review). Mol Med Rep 6: 459-465, 2012.

5. Ahmad A, Ginnebaugh KR, Yin S, Bollig-Fischer A, Reddy KB and Sarkar FH: Functional role of miR-10b in tamoxifen resistance of ER-positive breast cancer cells through down-regulation of HDAC4. BMC Cancer 15: 540, 2015.

6. Knirsh R, Ben-Dror I, Modai S, Shomron N and Vardimon L: MicroRNA $10 \mathrm{~b}$ promotes abnormal expression of the proto-oncogene c-Jun in metastatic breast cancer cells. Oncotarget 7: 59932-59944, 2016

7. Zhen L, Li J, Zhang M and Yang K: MiR-10b decreases sensitivity of glioblastoma cells to radiation by targeting AKT. J Biol Res (Thessalon) 23: 14, 2016.

8. Ma L, Teruya-Feldstein J and Weinberg RA: Tumour invasion and metastasis initiated by microRNA-10b in breast cancer. Nature 449: 682-688, 2007.

9. Short MW, Burgers KG and Fry VT: Esophageal cancer. Am Fam Physician 95: 22-28, 2017.

10. Lin Y, Totsuka Y, Shan B, Wang C, Wei W, Qiao Y, Kikuchi S, Inoue $\mathrm{M}$, Tanaka $\mathrm{H}$ and $\mathrm{He} \mathrm{Y}$ : Esophageal cancer in high-risk areas of China: Research progress and challenges. Ann Epidemiol 27: 215-221, 2017.

11. Xu H, Yao Y, Meng F, Qian X, Jiang X, Li X, Gao Z and Gao L: Predictive value of serum miR-10b, miR-29c, and miR-205 as promising biomarkers in esophageal squamous cell carcinoma screening. Medicine (Baltimore) 94: e1558, 2015.

12. Massagué J: TGFbeta in cancer. Cell 134: 215-230, 2008.

13. Mishra L, Derynck R and Mishra B: Transforming growth factor-beta signaling in stem cells and cancer. Science 310: 68-71, 2005.

14. Madhunapantula SV and Robertson GP: The PTEN-AKT3 signaling cascade as a therapeutic target in melanoma. Pigment Cell Melanoma Res 22: 400-419, 2010.

15. Georgescu MM: PTEN tumor suppressor Network in PI3K-Akt pathway control. Genes Cancer 1: 1170-1177, 2010.

16. Jamali L, Tofigh R, Tutunchi S, Panahi G, Borhani F, Akhavan S, Nourmohammadi P, Ghaderian SMH, Rasouli M and Mirzaei H: Circulating microRNAs as diagnostic and therapeutic biomarkers in gastric and esophageal cancers. J Cell Physiol 233: 8538-8550, 2018.
17. Livak KJ and Schmittgen TD: Analysis of relative gene expression data using real-time quantitative PCR and the 2(-Delta Delta C(T)) method. Methods Dec 25: 402-408, 2001.

18. Xu W, Yang Z, Zhou SF and Lu N: Posttranslational regulation of phosphatase and tensin homolog (PTEN) and its functional impact on cancer behaviors. Drug Des Devel Ther 8: 1745-1751, 2014.

19. Bahena-Ocampo I, Espinosa M, Ceballos-Cancino G, Lizarraga F, Campos-Arroyo D, Schwarz A, Garcia-Lopez P, Maldonado V and Melendez-Zajgla J: miR-10b expression in breast cancer stem cells supports self-renewal through negative PTEN regulation and sustained AKT activation. EMBO Rep 17: 1081, 2016 .

20. Wang W: Study of miR-10b regulatory mechanism for epithelial-mesenchymal transition, invasion and migration in nasopharyngeal carcinoma cells. Oncol Lett 14: 7207-7210, 2017.

21. Zhang Y, Liao RB, Hu LL, Tong BX, Hao TF and Wu HJ: The microRNA miR-10b as a potentially promising biomarker to predict the prognosis of cancer patients: A meta-analysis. Oncotarget 8: 104543-104551, 2017.

22. Tian Y, Luo A, Cai Y, Su Q, Ding F, Chen H and Liu Z: MicroRNA-10b promotes migration and invasion through KLF4 in human esophageal cancer cell lines. J Biol Chem 285: 7986-7994, 2010.

23. Carlsson J, Christiansen J, Davidsson S, Giunchi F, Fiorentino M and Sundqvist P: The potential role of miR-126, miR-21 and miR-10b as prognostic biomarkers in renal cell carcinoma. Oncol Lett 17: 4566-4574, 2019.

24. Zhang J, Yang J, Zhang X, Xu J, Sun Y and Zhang P. MicroRNA-10b expression in breast cancer and its clinical association. PLoS One 13: e0192509, 2018.

25. Hujie G, Zhou SH, Zhang H, Qu J, Xiong XW, Hujie O, Liao CG and Yang SE: MicroRNA-10b regulates epithelial-mesenchymal transition by modulating KLF4/KLF11/Smads in hepatocellular carcinoma. Cancer Cell Int 18: 10, 2018.

26. Moustakas A and Heldin CH: The regulation of TGFbeta signal transduction. Development 136: 3699, 3714, 2009.

27. Pickup M, Novitskiy S and Moses HL: The roles of TGF beta in the tumour microenvironment. Nat Rev Cancer 13: 788-799, 2013.

28. Zheng T and Yang J: Mechanism of transforming growth factor $\beta$ in patients with hepatocellular carcinoma. Chin J Hepatobiliary Surg 6: 425-428, 2016.

29. He Z, Dong W, Li Q, Qin C and Li Y: Sauchinone prevents TGF- $\beta$-induced EMT and metastasis in gastric cancer cells. Biomed Pharmacother 101: 355-361, 2018.

30. Katsuno Y, Lamouille $S$ and Derynck R: TGF-beta signaling and epithelial-mesenchymal transition in cancer progression. Curr Opin Oncol 25: 76-84, 2013.

31. Ma C, Wei F, Xia H, Liu H, Dong X, Zhang Y, Luo Q, Liu Y and Li Y: MicroRNA-10b mediates TGF- $\beta 1$-regulated glioblastoma proliferation, migration and epithelial-mesenchymal transition. Int J Oncol 50: 1739-1748, 2017.

32. Ouyang H, Gore J, Deitz S and Korc M: MicroRNA-10b enhances pancreatic cancer cell invasion by suppressing TIP30 expression and promoting EGF and TGF-beta actions. Oncogene 36: 4952, 2017.

33. Zhong H, Wang HR, Yang S, Zhong JH, Wang T, Wang C and Chen FY: Targeting Smad4 links microRNA-146a to the TGF-beta pathway during retinoid acid induction in acute promyelocytic leukemia cell line. Int J Hematol 92: 129-135, 2010.

34. Liu MX, Liao J, Xie M, Gao ZK, Wang XH, Zhang Y, Shang MH, Yin LH, Pu YP and Liu R: miR-93-5p transferred by exosomes promotes the proliferation of esophageal cancer cells via intercellular communication by targeting PTEN. Biomed Environ Sci 31: 171-185, 2018.

35. Liang HX, Sun LB, and Liu NJ: Neferine inhibits proliferation, migration and invasion of U251 glioma cells by down-regulation of miR-10b. Biomed Pharmacother 109:1032-1040, 2019. 